\title{
地方自治体 (福岡県)の建築関係組織の実態
}

\section{明治・大正・昭和初期}

建築活動の地方性に関する研究

\section{THE ACTUAL CONDITION OF THE ARCHITECTURAL ORGANZATION ON THE LOCAL AUTHORITY, FUKUOKA PREFECTURE, MEIJI, TAISHO, EARLY SHOWA ERA}

A study on the locality of building construction activities

片野博*

Hiroshi KATANO

\begin{abstract}
In this paper, the author defined the actual conditions of the architectural organization on the local authority, Fukuoka prefecture, especially the feature of two sector; one had a function relating to building and repairing, and the other to supervising the building law, before the last war.

The results of research are as follows ; the former sector had belonged to the civil engineering section and needed a long term to establish architectural organization, and the latter sector had an early chance of independence, because of supervising the building law. As two sectors were independent each other, the staff exchange between two sectors had not existed. The actual number of staff on both sectors had differed from the number which were regulated by the local authority law.
\end{abstract}

\section{Kelwords: locality, local authority. Fukuoka prefecture. \\ architectural organization. Mejil. Taisho eary Showa era \\ 地方性 地方自治体 福岡県 建築関連組織 明治 - 大正・昭和初期}

\section{1.はじめに}

環境を形成する建筑物以、大量生産を前提とした工業 製品とは異なる土地の固着性に低拠した一品生産という 特筫から、建設される場との係わりが强い。従って人間 がつくり出した社会環境の物的資産ともいえる環境財と して優れた建筑を建設し、残すためには、地域的条件が 考㞒される必要がある。また地域的条件は過去からの累 積により形成させるものといえよう。従って上記の条件 を探し出すために、まず地方を対象に歴史的展開の中で、 公共機関、民間による建設活動、あるいは設計者、材料 供給の特徵や建築教育 (機関) 等の実態を明かにするこ とが重要といえよう。また、変貌する今後の社会にあっ て地域的条件がどのようにあるべきかは、歴史的展開の 中で事象の発生とその背景（原因）の関係を導き出すこ とから得られよう。

このような前提を踏まえ、地方に扔ける建築活動の実 態を解明するために前稿では" 、福岡県に扣ける国の出 先機関の組織上の実態を明かにしたが、本稿では、地方 行政（行政組織としての「福岡県」）内の建築関連組織
の奏態を研究対象とした。また、期間的には近代国家の 確立された明治から、地方自治制度の变革前の第二次大 戦の終わりまでとした。この理由以次章で述べるように、 戦前の地方行政が戦後のそれと地方の権限を含めた地方 自治のシステムが異なっていたこと、既往の研究 ${ }^{2)}$ では この期間の建留関連組織があまり扱われておらず、地方 の実態例を提示することが重要との判断による。地方自 治体の中で県を対象とした理由的、

(1)地方自治にあって、戦前の県は国家機構の一部でもあ り、国の地方に対する施策を明らかにできること。 (2)地方の公共事業では府県が主体的に対処していたこと 等が該当する。

な拈、福岡県を対象とした理由は、北部九州の中心県で あり、多くの公共工事がなされたこと、早い時期から市 街地建築物法が施行された市を多く抱えていたこと等に よる。

本稿で使用では、福岡県の公式記録に相当する福岡県 統計書 ${ }^{3)}$ 、職員の動静を示す福岡県職員録 (4)用いて組 織の変遷を明らかにし、この他の資料としては建築学会

\footnotetext{
* 九州芸術工科大学環境設計学科 助教授.工博 Assoc. Prof., Dept. of Environmental Design, Kyushu Institute of
} Design, Dr. Eng. 
会員は、何らかの形で建設活動に携わっているとの観点 から学会員名簿 ${ }^{5}$ から福岡県仃を戝場とする会蕒をり久 トアップし確認の資料としている（会員名簿の記載事項

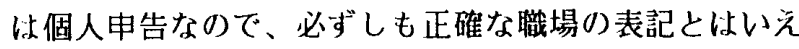
ない）。また、本稿では県庁内の建蚫関連組織の変遷の 実態を中心とするために、県仃が担当した具体的な建築 の設計や工事の詳細については扱わない。

本稿の構成は、はじぬに府県の所管事項を規定した戦 前の地方自治のシステムを述べ、以降具体的な県工事に 携わった営縓組織、市街地建築物法の施行に関する事務 を担当した組織の実態を明らかにする。後者は直接的な 建築生産活動に該当しないが、広義の意味で建築の質を 管理する部門であり、建築行政の一部であったとの観点 から加えている。また、最後に他拊県と福岡県との建築 関連組織の比較を行なう。

\section{2. 戦前までの地方自治制度}

戦前までの地方自治は、昭和 22 年に法律第67号によっ て制定された地方自治法とは、国との関係や職員（吏員） の任用が異なり、建築関係の組織もこれに規定されてい た。従って、ここでは制度上の特質を大略述べる。 2.1 苻県の事務（戦前の地方自治の特徵）

維新後の地方自治制度は、明治17年の布告第 130 号を 以て、公共工事を起こし、共用の地斥、建築物を随意に 処分し、金穀が公借できることを認め、他に扣いては人 民が地方行政に関与することを認めたことから始まり 、 拊県制、市制、町村制の公布により、法制化された経緯 をもつ。しかしこの地方自治体は中央と独立関係になく、 後者が前者を直接的に監督・指揮する体制にあった。す なわち、戦前の保県は独自の公共事務の外に、「従来の 法律（法令）、又は慣例により、及び将来、法律・勅令 により府県に付属する事務」を処理する役割がありマ、 地方官官制でも「第 5 条、知事は内務大臣の監督を承け、 内閣・各省の主務に付いては内閣総理大臣又は各省大臣 の指揮監督を承け、法令を執行し、部内に行政事務を管 理する」と規定されていた。地方公共団体への国の委任 事務では、寀議院選挙法、徵兵令、土地収用法、種痘予 防法、精神病者看護法、水難・行旅病人及び死人取扱法、 水難救護法と並んで土木関係では河川法、砂防法、道路 法によるもの、さらに都市計画法、市街地建築物法の運 用に関する事項が該当し、教育では小学校令等が関係し、 校舎の新・改・増・修築も含まれる ${ }^{8)}$ 。また付県固有の 事務は、主にその事業が地方税によって行なわれ、拊県 に職場をもつ官吏の給料を始め、建築関係では警察庁舎 建築修繥費、郡（区）役所建築修絽費、付県監獄建築修 緗費がこれに該当し、他の費目への流用が禁しらうてい $た^{9}$ ）。以上は、地方税規則（明治13年、太政官布告第16
条）にようもので、地方税をもつて支弁すべき費目とし て規定されていた。しかし、昭和18年になると戦時下に あって、自治行政の刷新と能率化を図るため、地方制度 全般を見直す大改正が行なわれ、付県及び市町村に対す る事務委任屿各省令をもって成しうることにされた ${ }^{10) 。 ~}$ 逆に言えばそれまでは各省との直接的な連繋山少なく、 主に地方の府県は内務省の監督下にあった。

従って: 戦前の府県の行なう事務は、学校教育のよう な例外を除くと、土木、都市計画、建築番査・監督は今 日とは異質な、主に上位の一つの省（内務省）との関係 で処理されていた点に特徴がある ${ }^{11) 。 ~}$

\section{2 府県職員の任用}

地方自治体 (苻県) の吏員（職員）は終戦後の地方自 治法のそれとは大いに異なっていた。先ずその長たる知 事は、身分的には天皇の勅令により徵用する意味から勅 任官（官選）であり、国の行政区長である面に重点が置 かれ、国家機関の一員としての役割が課せられていた 2)。知事の補助たる官吏は、内務部長、警察部長、理事 官、慜視、技師（以上奏任官）と、属、警部、警部補、 視学、技手（以上判任官）から構成され、これらの官吏 は地方官官制により規定され、地方に職場を有するもの の身分的には国家のそれに属していた ${ }^{131}$ 。具体的には、 知事は、内務大臣の監督を受け、各省の事務については 各省大臣の指揮監督を受けて法令・命令の執行を行なっ た。また知事の下級官庁及び部下の指揮監督権に関する 職務内容では、奏任官相当（技師を含む）の吏員につい ては功過・㤵戒を内務大臣に具申する権限しか有せず、 判任官（技手を含む）のみ知事により進退・㗹戒を行な うことができた点に特徵があった。県内の仕事を担当す る者でありながら、特に上級職員にとっては、現行の地 方公務員制度とは異質のシステムであった ${ }^{14) 。 そ し て ~}$ 官吏の定数も、奏任・判任官にあっては栜令で全体の定 数が決められ、その配分に関しては、主務大臣がこれを 各府県の状況を勘案して配分することになっていた ${ }^{15) 。 ~}$ 国家による地方官の配当の一例を示すと、昭和 9 年12月 27日勅令第 398号「地方学校営縉職員制」では、府県費 を以て府県を通して以下の建築技術者を置くことを認め ている。

$$
\begin{aligned}
& \text { - 学校営縒技師 専任 } 47 \text { 人以内（奏任官待遇） } \\
& \text { - 学校営纁技手 專任 } 118 \text { 人以内（判任官待遇） }
\end{aligned}
$$
そしてこれら学校建築の営縡の監督に関して技術供与を 行なう職員を置くべき拊県及びその定数は、文部大臣が 定めることになっていた ${ }^{18)}$ 。また大正 8年の都市計画 法の施行に伴い、各地で設置された都市計画地方委員会 においても、付県の所属吏員（地方委員を康わる）にあっ ては、地方支弁の給与でありながら身分的には国家（内

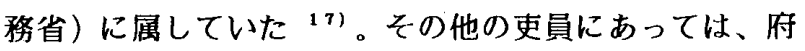
県の独自費用により、県吏員の採用ができ ${ }^{18)}$ 、国の吏 
員（官吏）たる上級職員と府県独自の裁量による下級睵 員から構成され、建築関係職員にあってい、技師と技手 が前者に属し、県吏員たる工手と㕍让後者に属していた。 ここで地方官官制による職階の内容の違いを示せば 19!、 勅任官は、天皇の栜令により任用する官吏で、高等官 1 、 2 等が該当し、奏任官は、高等官 $1 \sim 9$ 等のうち 3 等以 下に該当し、任用及び叙等は長官の奏䔍により栜載をもっ て行なわれ、任用には原則として試験合格者をあて ${ }^{20}$ )、 判任官は、勅任・奏任官の高等官の下に位置し、一定有 資格者の中から各省大臣、付県知事などの長官の権限を もって任免された。

一方、府県知事の指揮監督下にある市町村吏員につい ては、それぞれの市町村条例の中で定数が定められ、国 との一元的な連繋は存在していなかった ${ }^{21}$ 。ただし、 昭和18年 3月 9日の「町村制」改正では、戦時体制に入 り、国会一元化のために市町村選任方式の中央関与、中 央主権化が行なわれた ${ }^{221}$

\section{3. 営結組織の変遷}

3. 1 営䋧主務組織の変遷

明治初期の福岡県の営繥組織の移り変わりを、福岡県 史第四巻 ${ }^{23)}$ からみると、明治 3年の藩行政に公務局、 司祭局、司計局、警察局があり、その司計局に土木が属 していた。同 5 年には民務課、聴訴課、租税課、出納課 の 4 構成となり、土木・営䌜は租税課で扱われていた。 明治 7年には課内に科が設けられ、租税課に土木科が設 置された。以後の建築を扱う組織と分掌関係は不明であ

図1。福岡県の営繥組織の沿革
るが、明治13年から以、「福岡県統計書」 ${ }^{21)}$ が発行さ れ、データ的には昭和16年までトレー人できる。同統計 書によると、明治13年（版）では、勧業課（上位の部は 存在していなかった）に土木科が置かれ、同15年には土 木課に昇格し、常務・土木科の 2 科構成となり、文官・ 技官の区別恃不明であるが、判任官 8名、等外 6名の構 成であった。以後、土木課は吏員の増加や係の増設を経 ながら、明治 19 年の第二部所属、23年には第一・二部を 合せて内務部となり、その第二課に所属し、農工商係や 地理係等と並んで土木係となった。但し、全般的にそれ 以前の「課」が「係」に改正されているので、本質的に は地理係関係を除くと、従前の「課」時代と大きな相違 はないと思われる。建築関係（特に営縉関係）の組織が 独立した係を構成した年は、明治19～22年、同32年にあ り、前者は営繥掛、後者は建築係であった。しかし福岡 県議会の予算議決記録 ${ }^{25)}$ によると、この時期は監獄建 設が主であり、特に建設数の多い年ではなかった ${ }^{28) 。 ~}$

明治32年（版）には、特異な点がみられ、第二課所管 は同じであっても土木係の名称が消え、調査係、工事 ・ 建築・地理係の構成になった。県の統計書を資料とする と行政組織上（掛以上という意味で）、土木が存在しな い唯一の年（期間）といえる。翌33年（版）からは、土 木係が再登場し、替って建築係は姿を消した。課を廃し て再び部の構成になった明治38年には第一部内に建築係 の名称がみられ、この他には国費係、県費係、地方係、 土木係、地理係が含まれ、同年には県下の地域を分担す る土木管区 ${ }^{27)}$ も第一部内に設置された。明治40年から は数字による部の称呼が改められ、知事官房、内務部、

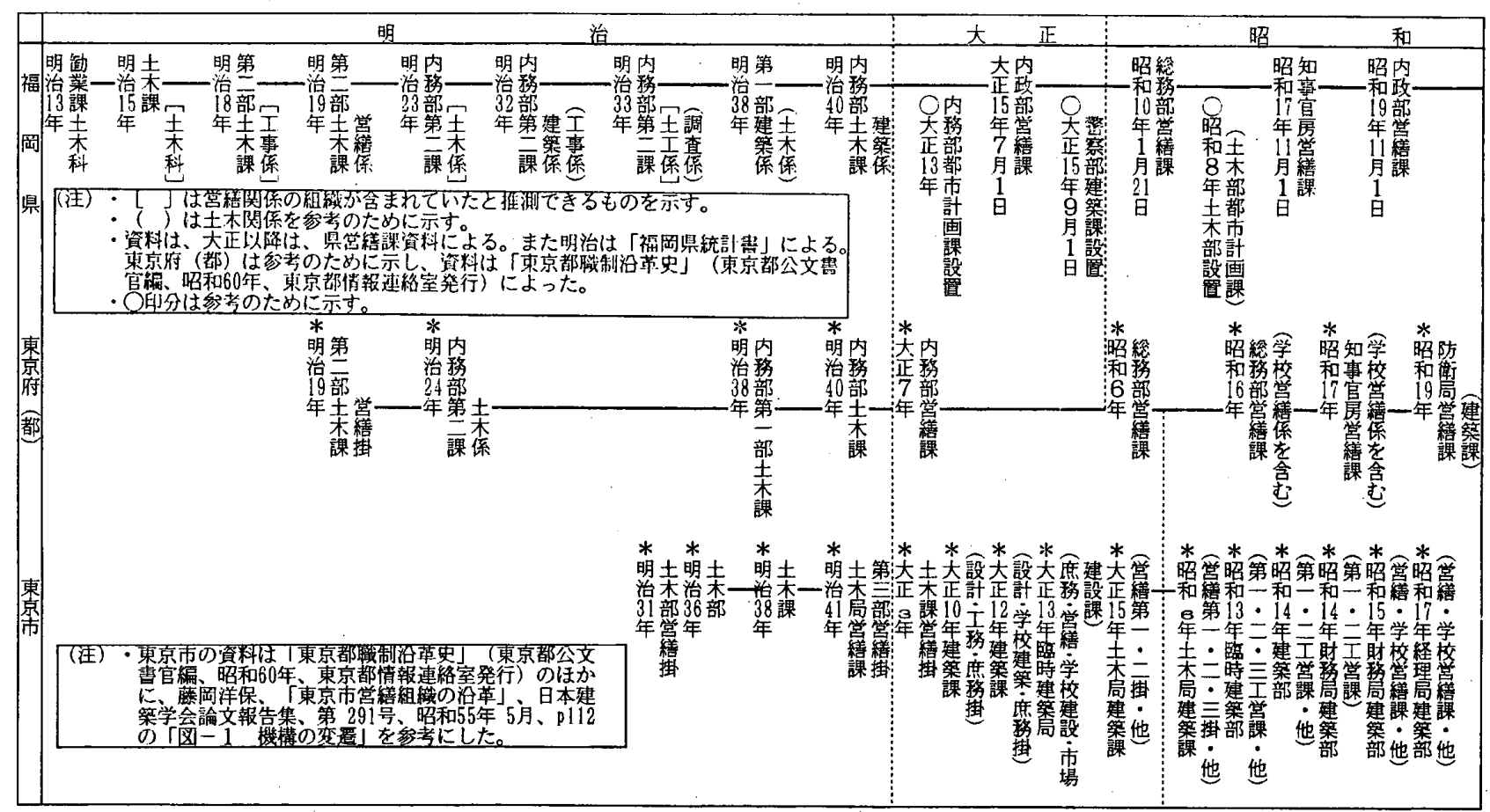


警察部、港務部とされ、内務部 8 課の一部として土木課 と土木管区が置かれ、こひ時期から大正 15 年の営繥課設 置に至までの間、県統計畫の中から、営繒・建築の名称 が姿を消し、内務部の土木課に含まれた。

一方、学会員名簿により、建築関係者を県庁の中から 確認すると ${ }^{28)}$ 、明治36年版で比、県庁第二課所属の准 員が一人存在（土木係と推測できる）し、同39年では准 員 2 名が県仃第一部建築係、同 41 年以准員 5 人が内務部 土木課職員として記載されていたが、中の一人の場合は 土木課建築係と明記されていたので、県統計書では不明 であった課の下位組織として建築係が存在していたこと が分かる。この准員は明治 43 年版の学会員名簿でも確認 できることから、一般的には土木課建筑係が存在してい たと判断しても不都合はないと思われる。しかしこれま での年度の学会員名簿では土木技手との表記のみで、建 築技手のものはなく、明治 43 版の土木技手の一人は別の 資料 29 )では、福岡県庁の工事監督として確認された。 また福岡県庁の設計者として知られている、三條栄三郎 は、明治 42 年の職員録の中で内務部営繥課技師として最 初に確認できた 30)。以上のことから、明治・大正期は、 建築営繥関係の組織は独立していた時期が若干あったが、 主に土木課所管であり、明治 38 年から建築係の存在が明 かになった。

また県職員録によると、大正 3年版では土木課の中に 県庁建築事務所、同 $4 \cdot 5$ 年版には臨時建築部の記載があ るが、詳細は不明であった（県庍は大正 4 年竣工）。

大正15年7月 1日になると、内務部に分掌事項が「建 築営縡及び監督及び補助に関する建築調査を職務内容」

31)に該当する営䋨課が置かれ、従来の土木課から独立 した組織になった。大正15年当時の福岡県統計書の吏員 の配当表によれば（但し、技官と文官の区別なし）、奏 任官 2 名、判任官 2 名、県吏員19名、属24名であった。 以後は、県庁内の組織に大きな変革はなく、昭和10年に は総務部、同17年には知事官房、終戦の押し迫った同19 年には内政部所属の営縡課となった。戦後の昭和 20 年 12

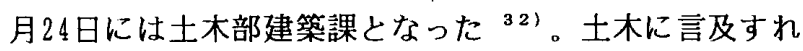
ば、昭和 8年10月 2日をもって課が廃され、部に昇格し、 これは大正15年 6 月 3日勅令第147号「地方官官制」の 全面改正により、内務大臣が緊急性により拊県を指定し て土木部を設置することを可能にした結果であり ${ }^{33) 、 ~}$ 福岡県の導入時期の差（ 7年）と、地方組織に対する国 の指揮監督の高さがみてとれる。

次に、府県 (地方自治体) の内部組織の変遷が明かに なっている東京府（都）、東京市との比較を行なうと ${ }^{3}$ 4)。明治期の土木課所管の頃は両府県と東京市に大きな 違いはないが、営縡課の独立は東京府の方が 8 年早く、 東京市は 5 年早い。総務部への配置では東京府が 4 年早 く、知事官房等への機構改革では福岡県と東京府は時期
図 2. 営繥課職員の在職状況

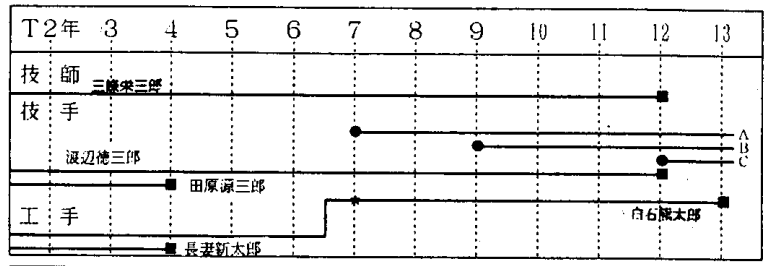

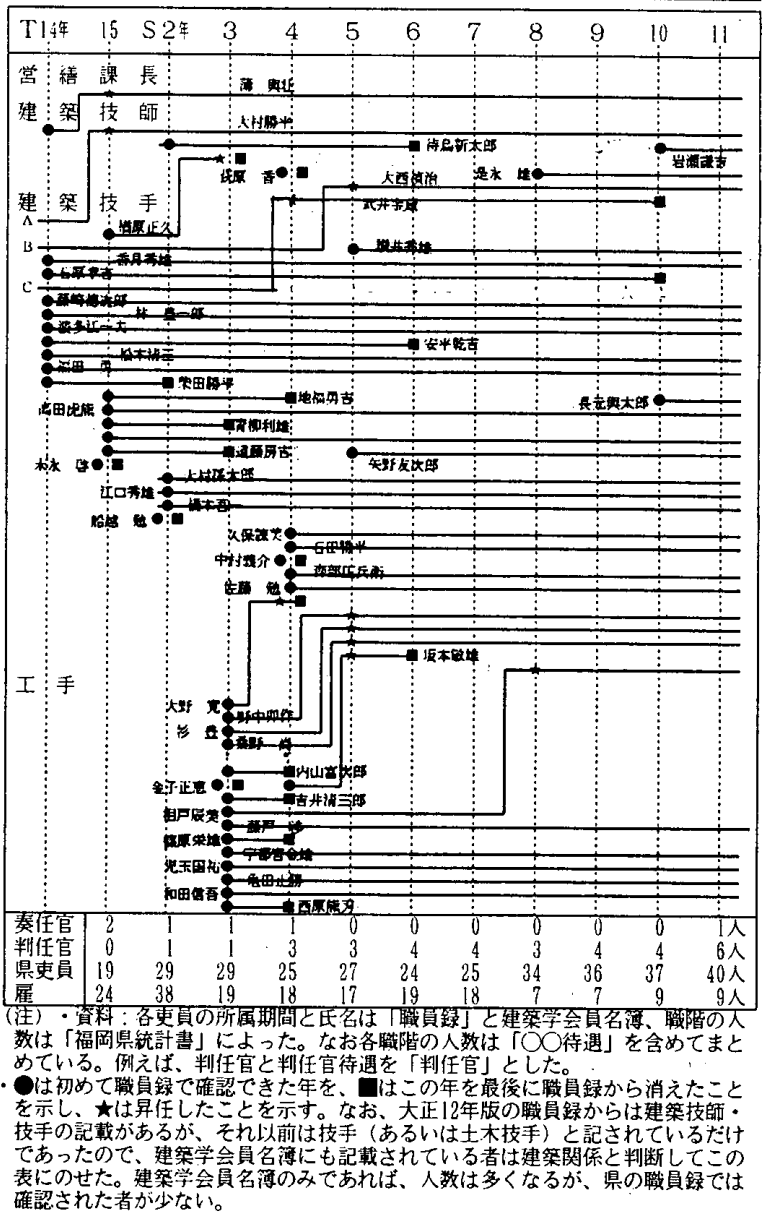

を同しくしている。な打、東京市は昭和13年には臨時建 築部になっていた。（以上は図 1参照）

\section{2 営縡関係職員 (吏員) の構成}

福岡県統計書を用いて県営綪関係組織の変遷を明かに してきたが、ここでは別の資料の福岡県職員録 ${ }^{351}$ から 営繒技術者個人を、移動を含めて明かにする。この資料 は従前の統計書が県の公の記録であるのに対して、名簿 とあるように所属する吏員の名前が年毎に記載されて、 人の動き（移動）を捉えることが可能であるが、内部資 料的な性格を有する点に注意が必要である。図 2 はこの 職員録を資料に、営縉関係の仕事に携わった技術者の変 遷を示すものである。な扢この図では県吏員にあたる「 工手」までを扱い、「雇」に付いては割愛した。この図 から分かることは、大正14年以前は技師の数も少ないが、 以後は技手の数が増加し、昭和 3 年になると工手が加わ り、営縉課では34人の增加に至り、以後、この名簿から 消える技術者も見られるが、概ね昭和 11 年まで継続して 
営繕課に属している。すなわち、営繒課に属した吏貣は 長期間にわたって勤務して括り、下位け職階から昇任す るとはあっても、同一の組織に所属していた。これ恃東 京市の営緗組織と同じといえる ${ }^{38)}$ 。営繒課の設置され る一年前の大正14年から昭和11年（入手できる瞕員録の 最終年）まで継続して営縓課に勤務した技師（課長を含 む） 3 名、技手は 6 人、大正 15 年か 5では技手 2 人、昭 和 2年からでは技手が 3 人、工手（昇任分を含む）にあっ ては昭和 3 年から9人が該当する。またもう一つの建築 関係の組織である警察部建築課との人事交流も職員録か らは存在が確認されなかった。これは同じ県庁内であり ながら内務部系と警察部系では組織上異なることと関係 があるようだ。

この他に、先に「2.2 府県職員の任用」で指摘したよ うに、昭和 9 年の勅令第 389 号をもって、文部大臣は各 苻県に学校営繥技師並びに同技手を配置することができ るようになったが、この分に関しては、県統計書、職買 録からは明かにされず、学会員名簿の昭和 12 年版に早稲 田大学出身の県学校営縡技手が学務部学務課に所属して いることが明かになった。ただし、東京府や東京市と場 合は、営縡課の中に学校営絸掛が所属し、福岡県のよう に学校事務を担当する部局に技術者が含まれるケースと は異なっていた。

営繯課職員の個人的記録がないために詳細は不明であ るが、技師・技手にあっては、建築学会員名簿から高等 専門学校にあたる名古屋高等工業学校、東京高等工業学 校、各種学校にあたる工学院など、地元福岡県以外の学 校を卒業した例が見受けられる 37。地元福岡県では明 治 29 年に県立福岡工業学校、同 39 年に浮羽工業学校が設 立され、両校とも建築科を開設していたが、これらの卒 業生は県吏員の工手に相当するとも推測できる ${ }^{38) 。 ~}$

営䋨技術者の個別経歴は明かでないが、営繕課長を努 めた薄與壮について、その履歴を示すと 39)、明治18年 8月29日に福岡県に生まれ、同38年には福岡工業学校建

図3. 県議会決定による福岡県の営縡工事
留科を卒業、同42年に名古屋高等工業学校建築学科を卒 業し、大正 4 年 5 月に海軍省経理局建筑工事啒詎となり、 同 7 年 5月文部省建築課虽、同 9年 9月文部技師、同 10 年今治市技師を経て、大正13年に福岡県建築技師となり、 同15年に初代営繙課長に昇任し、昭和21年 2月の退職ま で22年間にわたり課長瞕に就き、その後も福岡に留まり 建築士会会長などを努めた経歴をもつ。

営繥課の組織について県統計書と職嘪録を主たる資料 にその実態を明かにしてきたが、二つの資料は必ずしも 同じ内容でなかった。すなわち県統計書では県職員録よ り吏員の記載数が少なく、特に奏任官待遇の技師と判任 官待遇の技手にこの傾向が強い。県統計書は外部に対す る、職員録は内部の資料であることから、前者は地方官 官制で決められた定買枠を、後者は吏員の実情を示して いるといえよう。さらに、別の組織である都市計画課に は奏任・判任官が多く配当されていたことから 40)、営 繥活動の実態にあわせ国の決める技術者の定員枠とは別 に独自の活動を行なったのではないかと思われる。

\section{3 福岡県の施設建設状況}

図 3 は、明治12年から昭和 20 年までに福岡県議会にお いて可決された建築物の新筑・改築・増築工事をそれぞ れを一件として用途別(教育、勧業、行政、衛生、社会、 監獄）に分けたものである ${ }^{41)}$ 。以下に、この図から得 られた特徵とその原因を明らかにする。

・明治12〜15年：明治12年は、その前年に制定された「 郡区町村編成法」により従来の大区調所を使用していた 郡役所を業務の吏員の增大のために修䋸・改築が行なわ れた。翌13年には福岡圈内に 6 中学と 13 の中学校分校を 設置するとともに、勧業試験場内に農学校を設置するこ ととなり、計200教育施設が新設されることになった。 なお明治 16 年には教則改正により 6 中学校を甲種の県立 中学とし、3校を乙種として公立に移管した。この時期 は、教育施設の設置と郡制設置による行政施設の初期整 備の時期であったといえる。

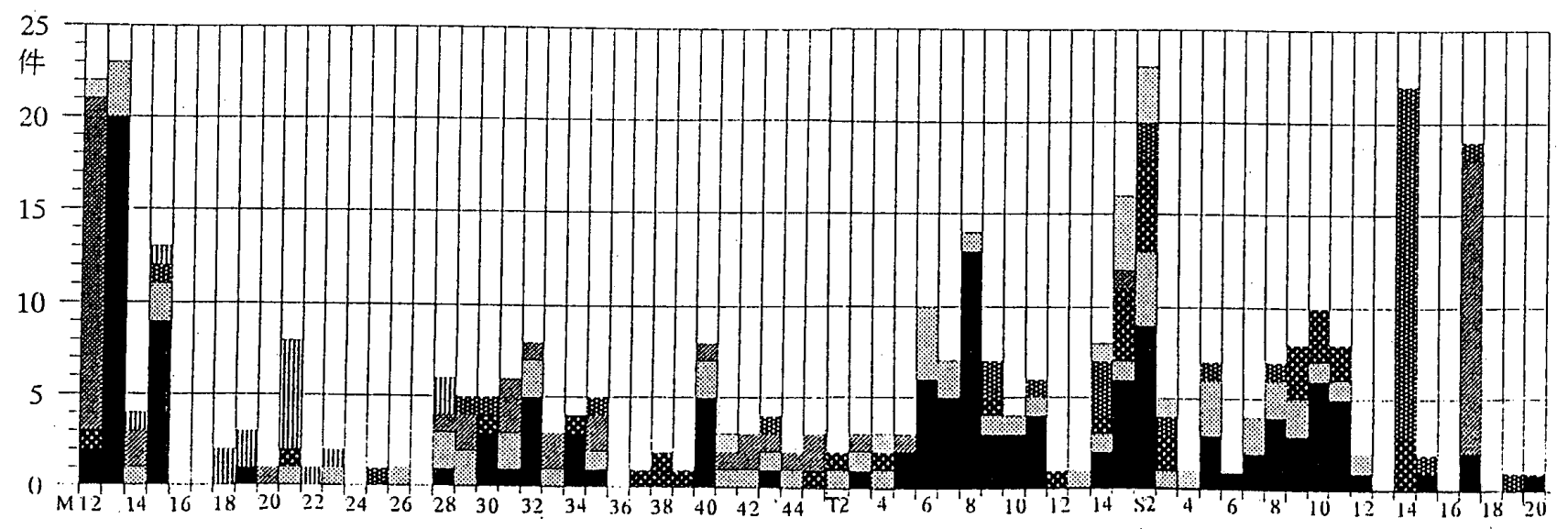

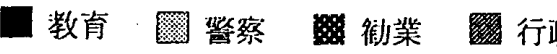

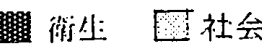

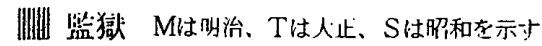


・明治16〜27年：この時期は建設量の少ない時期にあた るが、その中でも監獄建築の建設に特徵がみられる。こ れは明治13年に、当時の大蔵師松方正義が増税を敢行し、 その政策の中で従来中央財政支弁の府県建築修繬費・府 県監獄費・同建築修繒費を地方支弁としたことが理由で

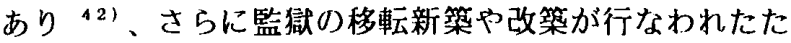
めであった。この当時の県の営縷は第二部土木課営縡係 が該当するが、司法省大臣官房営繥課に福岡監獄建築場 13)に技手が数人勤務していたことから、県管理の建築 物ではあるが、司法省技術者による中央設計・監理の可 能性が高い。

・明治28〜35年：日清戦争の勝利による日本の貨幣資本 の増大とそれに伴う資本主義経済の進展と関係して福岡

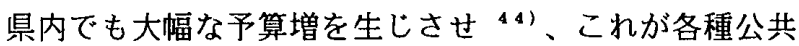
建築の建設に結び付いた。また明治28年には実業学校教 育法が制定され、国庫金15万円が支出され、福岡県内で は福岡工業学校（28年）、同久留米分校・同小倉分校（ 30 年設置、34年独立) 、福岡農業学校（32年）等が開設 され、新たな校舎の建設となった。また郡役所・整察署 の建設も以前と比べ逐次行なわれるようになった。

-大正 6年〜11年：第一次大戦による好況と政府の教育 革新により、教育施設が拡充され、建設量の增加と結び 付いた。大正 6年、内閣に設置された臨時教育会議は、 明治30年代に整備された教育制度を拡大・充実するもの であり、特に中等・高等教育機関の拡充に力が注がれた 15)。福岡県内では第一次大戦による北九州地域の産業 発展とこれに伴う高等教育機関への進学の増大により大 正 5 年頃からの工業学校や中学校の充実をさらに進展さ せ、同 8年以降は国の教育方針のもとに本格的な教育施 設の拡充に取り掛かった。この時期からは中学校の新設 と共に、郡立や市立の高等女学校・中学校を県立に移管 し、これに伴い新築や改筑が多く実施された。

-大正 14 年 昭和 4 年 : 大正 9年の戦後不況は関東大震 災（同12年）、金融恐慌（昭和 2年）により一層深刻化 したが、福凧県にあっては、大正12年〜昭和 4 年の減少 を除くと建設件数は多く、特に大正14年から昭和 2 年に かけては絶対数の多さと增加率の高さがみられる。これ は、天然資源に恵まれていたこと、県民福祉に係わる施 設が国の方針による地方財政の緊縮化を生しさせ、長年 計画のみに終わったが、昭和 2年頃から、「地方の発展 を促進させる事業であれば必ずしも抑制しない」とする 知事の方針転換とも関係する 48)。またこの時期は失業 対策の一部となる土木工事と共に、教育・勧業・治安・ 社会面に扔いて政策に偏りのない施設の拡充が図られた。 因みに、営䌟組織が独立した課となったのも、警察部に 建築工事の監査機関となる建築課が設置されたのもこの 時期であった。

- 昭和 5 年 11年 : 昭和 6 年の件数の減少は、予算は増
加したものの失業対策事業に集中使用され、婜急事業以 外以見合わさせた結果であった ${ }^{401}$ 。教育施設関係では 福岡農士学校（昭和 6年）、同農士道場（同 9年）、戸 烟中学校（同10年）の新規建設を除くと、他以改・増留 であり木造から鉄筋コンクリート造に転換され、この時 に打いて福岡県内の中等教育施設は一応の完成をみたと いえる。また昭和 2〜11年にかけて150警察署が老朽化 と職員の增員により全面的に改築され、昭和 2 年竣工の 黒木警察署以外はすべて鉄筋コンクリート造であり、15 件中、12件は昭和 5 年から11年の間に竣工した。

- 昭和14〜20年：昭和14年と17年に建設件数の集中がみ られるが、前者は花柳診療所が県下19力所に、後者は地 方事務所が16力所に建設された結果であり、戦時体制に 入ったこの時期では、大規模な建築はみられない。

以上、明治 12 年から昭和 20 年までの福岡県議会の議决 を経た建築の用途別の割合を示すと、第一位は教育施設 （37.9\%）、第二はほほ同じ割合で行政施設（16.6\%） と警察施設 (16.3\%) が占め、以下衛生施設（11.0\%）、 勧業施設 $(10.1 \%)$ と続き：5\%未満として監獄・社会 施設が該当する ${ }^{48)}$ 。県建築職員が直接担当したか否か を別にすれば、地方営縜にとって学校建筑がその多くを 占めていたことになる。

図 3 は県営建筑工事数を示したものであるが、現在の ところ営緗課がどのように関与（設計、監督、施工等） したかの詳しい実態は不明である。前述したような陣容 をもつ組織であったから県内の営䋨工事の大部分を担当 していたことが窺えるが、福岡県内の大都市市庁舎建設 （ただし大正・昭和の二代目にあたる）では、若松市（ 大正11年) が清水組、福岡市（同12年）が片岡 安、久 留米市 (昭和 3 年) と門司市 (同 5 年) が倉田 健 (九 州帝国大学建築課) の設計であり 49)、営繥課が担当し た例は、戸畑市役所（昭和 8年）と大牟田市役所（同10 年) であり、県知事がその管内の自治体行政に関して監 督権を有す ${ }^{501}$ といえども、営繥に関しては、当てはま るとは言い難い面がある。これは河川法や道路法あるい は都市計画法のような法令に基づく事務に属さぬためと 思われる。

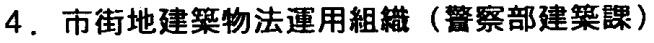 \\ 4.1 建築課の浻革}

県統計書の発行された明治 13 年以来の確認では、福岡 県の警察機構は、警察本部、警察本署、警察署と名称を 変更し、明治23年に警察部となるや終戦まで（地方自治 法の制定された昭和 22 年）この組織が内務関係と並んで 県行政を二分する形で継続していた。

警察部の分掌事務以設立直後から明治29年までは、警 察課、保安課など今日と同しような役割を果たしていた 
図 4. 建築課職員の在職状況

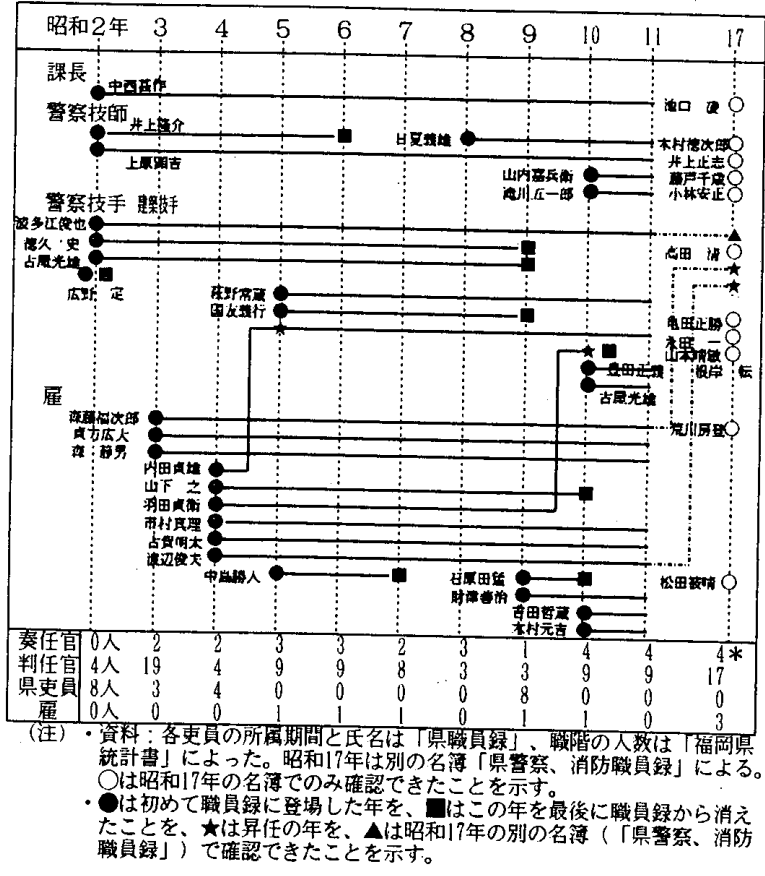

が、翌30年には医事及び薬事、伝染病予防、飲食物等に 関する事項を所掌する衛生課が加えられ、さらに工場監 督及び取締り、汽缶取締り、労働災害等を扱う工場課が 大正 9年に設置され ${ }^{511}$ 、同15年 6月 3日公布の勅令第 47 号「地方官官制」の全面改正により 521 、福岡県では (福岡県) 庁中達第16号をもって同年 9月 1日に、警察 部は 9 課構成となり、新たに市街地建築物法の運用を事 務とする建築課が誕生した。この建築課の分掌事務は、

一、市街地建築物法令施行に関する事項

二、警察取締りに属する建造物の取締りに関する事項

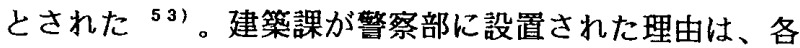
種の取締りに関する事務は全てこの部で担当していたこ とと関係し、部内に工場課、衛生課が設置されたのもこ の理由による。また中央各省庍の構成も、今日のそれと は異なり、文部省の教育関係を除くと内務省に所属して 扣り、この直轄下部組織として府県が存在し、取締機関 としての警察部の役割があった。

周知のように、市街地建築物法は大正 8年 8月 4日に 公布され、同年に制定された都市計画法と補完的関係に ある。すなわち都市計画を行なうために直接必要な集団 規制を適用しうる市街地建築物法の特質により、全国一 律の法適用ではなく、地域毎にその施行が決められ、福 岡県内では以下のような制定状況であった 511。

-大正15年10月：福岡市、門司市、小倉市、若松市、 大牟田市、八幡市

- 昭和 2年 3月：久留米市、戸畑市、後藤寺市、伊田町 - 昭和 8年12月：飯塚市

この中で市街地建留物法の全面適用を受けたのは後藤 寺 市、伊田町、飯塚市を除く8市であった。以後も逐次該
当地域の指定が行なわれ、炤和12年の末までに11市5町 が指定された。因みに市街地建築物法の全面適用山大正 9年の第一回目には6市の指定地が決定され、同15年ま でに52市町村が指定を受けたから、福岡県内の市街地建 築物法の全面適用は早い方といえる。また昭和15年の国 勢調査を資料に、各府県に打ける市街地建築物法の全面 適用を受けた市の人口の合計を調べると 55)、福岡県は 6番目に位置し（全面適用の市人口合計 $=1268$ 干人、全 県に対する割合は約 $41 \%$ ）、これは愛知県の1328干人に 続くものであった。従って福岡県の建築課が扱う物件数 は、全国の中でもかなり多かったといえる。

建留課の組織は大正15年の設置から昭和 2年までは県 仃内のみの組織であり、以後に各警察署に担当官が派連 され、終戦までは組織の変更はなかった。

福岡県に找ける建築課の沿革は上記のようであり、終 戦後の昭和 20 年 12 月 24 日には警察部から土木課に移管さ れ、同時に営緗課の業務も吸収する形で従前とは分掌事 項の異なる建築課が設置され、総務・監督・住宅・棠縉・ 調査係の 5 係の構成になった。本質的に終戦の前後では 分掌事務の内容、目的、行政運営の方法が異なり同一レ ベルで論ずることはできないが、限定された事項、すな わち県工事の設計、施工、維持・修綁を扱う営縡課より は、住宅・調査行政を含めた所謂建築行政が戦後の県の 組織の母体になったともいえる。これに関しては戦前の 取締りを事務の中心とした警察部建築課が母体であった ともいえよう56)。

\section{2 建築課職員の構成}

県職員録を資料とし建築課の吏員の構成を図 4 からみ ると、大正15年版には記載がなく、翌昭和 2年版では、 課長 1 名、警察技師 2 名、警察技手として 4 名の名前が あり、この時点では県㕂内のみの組織であった。昭和 3 年版になると、県庁内の組織と、実際の指導を現地で行 なう警察署所属の吏員が登場し、小倉署、福岡署、若松 署、門司署に担当者が置かれ、昭和 4 年になると、久留 米署、箱崎署（現福岡市内）、大牟田署、同 8 年には後 藤寺署、同 9年には飯塚署、同10年には直方署の担当者 が建築課の中に加えられるなど、県下各警察署に建築法 規の運用を管理する職員の配置は、市街地建築物法の適 用時期と関係が深い。また各警察署の配属は、昭和 3 年 にあっては、技手 1 名、㕍 3名であったが、翌 4年にな ると雇が 9 名となり、以後は市街地建築物法の適用地域 の拡大に伴い、技手の半数と雇の殆どが各警察署担当と なり、昭和11年には技師が八幡警察署所属となっていた。

また図 4 から洯察部建築課に所属する技術職員の動き （移動）を知ることができる。これによると、昭和 2年 から同11年まで逐次人員増が行なわれ、昭和 2年の 1人 から、同11年には18人となったが、営縡課の技術者数31 
人と比べるとその差は大きい。しかし技術者の在籍状況 恃営繥課と同し傾向があり、昭和11年以降が不明である ものの、約半数が建築課へ赴任以来同し職場に康務し、 かつ営縉課から建築課へ移籍された例は見られなかった （因に昭和 4 年に竣工した県警察庍舎の中で建築課と営

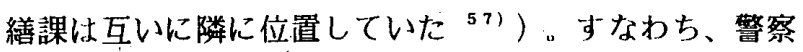
部本来の分掌である取締りを専門とする集団であったこ とが分かる。

図 4 中に示す昭和17年は膱員録とは別な資料（県䇾察・ 消防職員録）によるもので、この年は建築課長 1 名、技 術課長 1 名、技師 3 名、技手 8 名、扈 1 名であった。入 手できる資料の関係から昭和11年と同17年の両方の年に 確認できた者は技手の 3 名だけであった。

この建築課の職員構成を営繥課の場合と同しょうに、 県統計書加ら明加をると、奏任官・同待遇（技師相当） は大正 15 年から昭和 2年版までは 0 人であり、これは初 代建築課長の中西甚作が都市計画の地方技師に就任した 結果でこちらの定員枠に含まれていた。以後同16年版ま では $2 \sim 3$ 名で、昭和 9年に 1 名になるが、翌年からは 4名になった。一方、奏任官・同待遇（技手相当）は昭 和 3年の19名は例外的で 3〜9名であり、一定している とは言い難く、さらに多い年には職員録記載の倍以上を 推していた。県吏員も同様に0〜8名と一定していない。 扈は 0 人か 1 人であり、職員録の記載とは大幅に異なり、 県統計書の県吏員と雇を含めて職員録の扈としても差が ありすぎる。この理由は、営繥課のところで述べたよう に、公式資料となる県統計書の示す組織と職員録により 明かにされる実際の仕事を行なう組織とは異なっていた と判断したはうが適切であろう。

建築課所属の技術者の個別経歴は明かでないが、建築 課長を努めた中西甚作につて、その履歴を示すと ${ }^{58) 、}$ 山口県出身で明治 24 年 3月に生まれ、同 43 年 9月岡山高 等学校入学、大正 2年 7月同校を卒業し、同年東京帝国 大学工科大学建築科入学、同 5 年 7月卒業した学歴をも ち、卒業後は河合浩蔵建築事務所で働き、大正 9 年 2 月 都市計画地方委員会技師（内閣）、同地方委員会勤務（ 内務省）大阪、同兼務で大阪拊技師（内閣）、同 6 月内 務省建築課勤務（大阪府）、同11月内務部営繥課勤務（ 大阪府）等の大阪での経歴をもち、大正13年 7月都市計 画地方委員会技師（内閣）として福岡県に赴任し、同 15 年地方技師兼務 (福岡県) 、同福岡県警察技師、同警察 部建築課長を務め、昭和 16 年 6 月 14 日に退職した。初代 建築課長の職につき退職までの16年間にわたり建築審査 行政をして担当していた。また、昭和11年の日本建築学 九州支部の発足にあたっては、その設立に尽力し、初代 支部長を努妰 59 経験をもって扰り、行政上の手腕が かわれたものと思われる。
表 1 . 各府県の営縉・建築組織

\begin{tabular}{|c|c|}
\hline \multicolumn{2}{|c|}{ 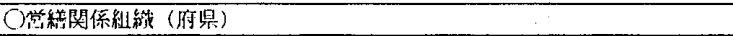 } \\
\hline 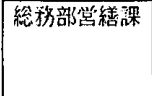 & 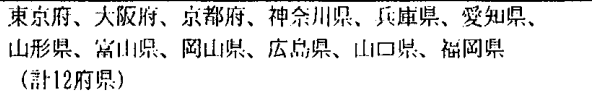 \\
\hline 経诮部營縉課 & 岐率県、長野県 (棓| 2県) \\
\hline 土小新管理課 & 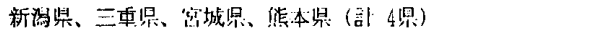 \\
\hline 経珮部土木課 & 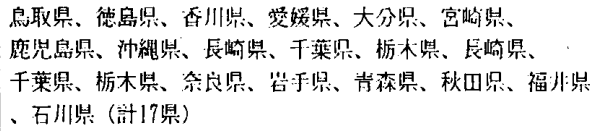 \\
\hline 上木部総務課 & 静岡県 (訃 1県) \\
\hline 総猛部会計課 & 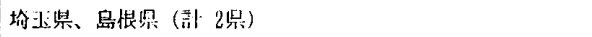 \\
\hline 総䅂部庶務課 & 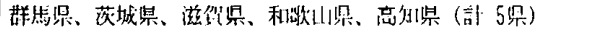 \\
\hline 経済部庶務課 & 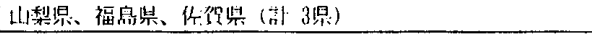 \\
\hline
\end{tabular}

\begin{tabular}{|c|c|}
\hline \multicolumn{2}{|c|}{ 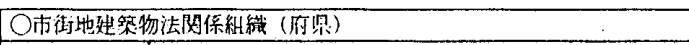 } \\
\hline \multicolumn{2}{|c|}{ 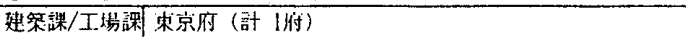 } \\
\hline 建 架 諜 & 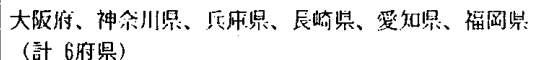 \\
\hline 建策下場謎 & 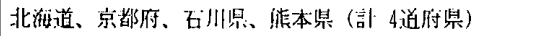 \\
\hline I場 課 & 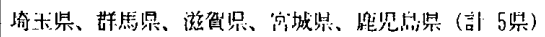 \\
\hline 学弱課 & 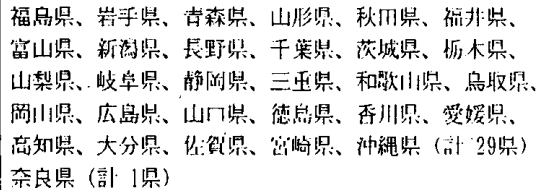 \\
\hline & 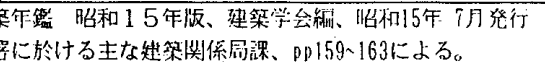 \\
\hline
\end{tabular}

\section{5. 福岡県と他県との比較}

上記に述べた福岡県の建築関連組織（営䌅課、建築課） が全国レベルでどのような位置づけができるか以下にま とめる。

\section{5,1 営繥課関係}

現在のところ、他府県内の営繥組織の実態を経年的に 明かにした既往の研究は少なく ${ }^{80)}$ 、全国の中で明確に 福岡県を位置付けることはできない。従って、ここでは 昭和 14 年 15 年頃の地方自治体の建築設計・監理をどの ようなセクションが担当していたか建築学会編・発行の 「建築年鑑、昭和 15 年版」の「XI．諸官庁に扔ける主な 建築関係局課、2．地方官庁」 ${ }^{811}$ を資料として地方自 治体（但し苻県分の夕）の営繥担当組織を明かにする。 この資料によると、福岡県と同しょうに総務部営縡課を 設置させている府県は、東京府、大阪府、京都府、神奈 川県、兵庫県等の計 12 県であり、全体の $26.1 \%$ に相当す る。これと同しような経済部営繥課に該当するのは、岐 阜県、長野県の計 2 県、土木関係の部、課に所属する例 が、新潟県、三重県をはしめ計21県（全体の $45.7 \%$ に相 当する) である。庶務課、会計課に属するものは計10県 存在していた（21.7\%に相当）。府県の中に「部」を設 置する場合は栜令を必要とし府県の判断で組織を新たに 設置することはできなかったが、下位の「課」にあって は府県の独自設置が可能であり、それぞれの営絽工事の 実情に合わせて種々異なった組織をもって対応していた

（表1を参照）。また、営緢課以外の課の分掌に該当す る県では係が担当していたが、この実態を同建築年鑑、 昭和 15 年版、同昭和 16 年版「IV. 竣工建築物」 ${ }^{62)}$ から 
明かにすると、青森・群馬・静岡・滋賀・奈良・香川・ 大分県は建筑係、岩手・栃木 - 群馬 - 茨城 - 山梨・福井 和歌山・島根・沖縄県は営繒係であった。な招同資料に よると市レベルでは长崎市の営縓課を除くと「建築」課 と称呼する例が多い。

府県の一般営縖と比べ、異質なものに学校建築営縖が ある。先に戦前の地方自治の特徴で述べたように、官吏 の定員と府県への配置は勅令をもって行なわれ、教育に 関しては、勅令第 398 号の地方学校営縜取職員制（昭和 9年）によると述べた。ここでは「XI．諸官庁に打ける 主な建築関係局課、2. 地方官庁」の中から府県の配当 状況をみると、沖縄県を除く府県に配置され、千葉・茨 城・秋田・福井・石川 - 鳥取・和歌山・德島・香川 - 鹿 児島県の10県が担当に技手を置き、残りの府県には技師 が置かれた。福岡県の場合は後者の技師配置県であり、 国の基準による技術者配当にあっては福岡県は全国的レ ベルにあったといえる。

\section{2 建築課関係}

市街地建築物法の管理（運用）を行なう組織を、営繥

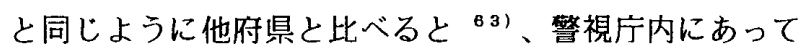
建築課と工場課の 2 課が存在する東京都を除くと、他の 府県は䇾察部の所管であり、保安課管轄が多く、29県（ 全体の $64.4 \%$ に相当する) が該当し、次ぎに建築課を独 立させている府県は福岡県を含む大阪府、神奈川県、兵 庫県、長崎県、愛知県の 6 県 (13.0\%に相当) で、その 他の工場課所管とするのが 5 県（1.5\%に相当）、労務 課に属するのが 1 県（奈良県のみ）である。昭和15年当 時福岡県の警察部は、高等課、特別高等課、警務課、保 安課、刑事課、衛生課、工場課それに建築課を含めた 9 課の構成 ${ }^{80)}$ であったから、市街地建築物法の事務を専 門とする組織であったといえる。な扔、建築課の所掌内 容となる市街地建築物法の各府県内に扔ける全面適用市

[ 注]

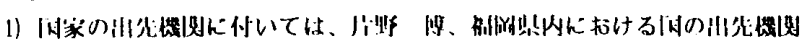

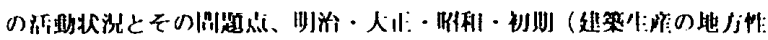

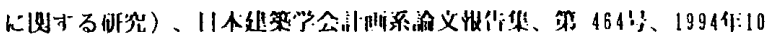
月、рD133〜141、にて四らかにした。

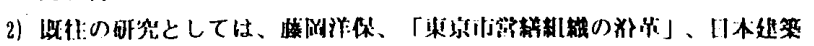

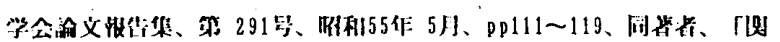

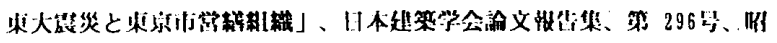

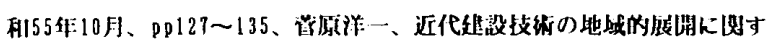

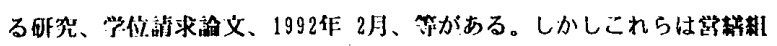

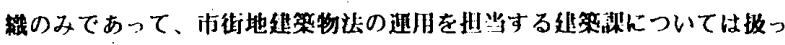
ていない。

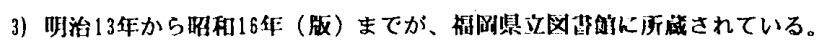
最行の 2 年分は名称が異なる。明治15年湖は久番であった。

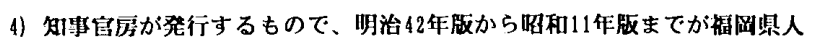
事媇に所成されている。

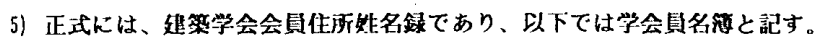
明治22作分からあり、同39年服までは仨狮きであった。
の規模（人口を指標とする）に言及すれば、昭和15年の 国勢調査結果を資料にすると、1位の東京府は6779千人 で付の人口の約 $86 \% 、 2$ 位は大阪府で3614千人、約 $75 \%$ 、 3 位は神奈川県で 1462 干人、約 $67 \%$ 、4 位は兵庫県で 13 56 干人、約 $42 \%$ 、5位は愛知県で1328干人、約42\%であ り、福岡県は6位に位置していた（1268千人、約41\%）。 このことから福岡県の建築課は全国的にみても扱う事務 は多く、これを図4のような組織が担当していた。

\section{6. 結 語}

以上、福岡県に扣ける営䌂課と建築課の沿革と職員構 成の実態をみてきたが、以上の結果から次のことが明か になった。

営繥課と建築課には相違があり、営繥課にあっては、 土木に打ける河川法や道路法などの法令を扱う事務と異 なるために独立した組織である「課」の設置は実際の事 務に比べ遅れ、明治・大正期にあっては主に土木関係の 一部に属し、「営縓課」の設置には時間を要した。一方、 市街地建築物法を担当する建築課は、最初から法令を施 行するために設置された。また両課とも職員（吏員）の 構成は、2 章で述べたように国からの配当により上級職 員が採用され、県独自採用の下級職員に限られる二極構 造がとられ、かつ定員が明確に規定されていたが、本稿 で指摘したように職員数については、県統計書と県職員 録の記載には違いがあり、県職員の方が実態を示してい るいえる。また職員の在籍状況からは営縡課と建築課で は、両者の人的交流 (移動) は夕られず、建築関係の組 織でありながらまったく別の事務といえ、かつ専門技術 者として長期にわたり同一の職場に勤務する者が多く存 在していた。

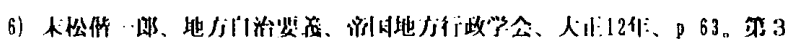

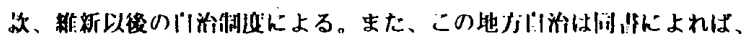

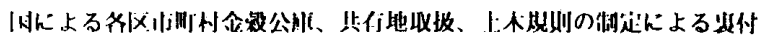
けがあった。

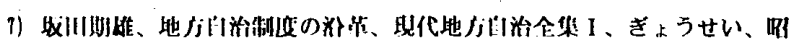
利52作 2月、 552 による。

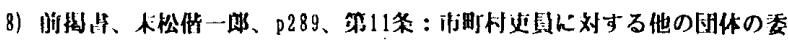

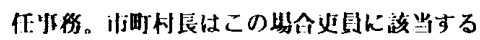

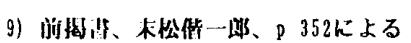

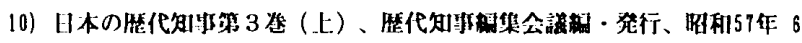
月、P 64 kよ。

11）昭和25年に制定された地方自治法では、地方の独立性が禹められ、内狢

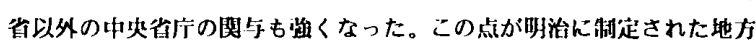
自治法とは筫なっている。

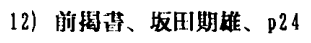

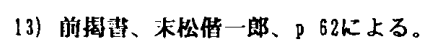

14)同下、D $69 k よ る 。$ 


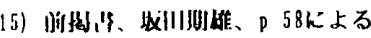

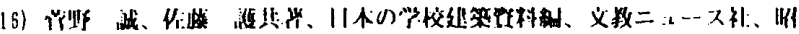
利58任: 7\%小, p276k卡る

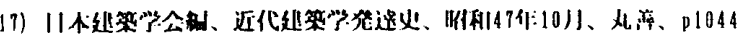

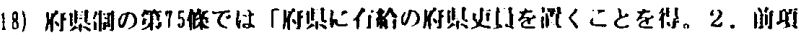

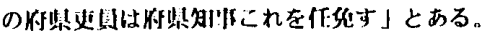

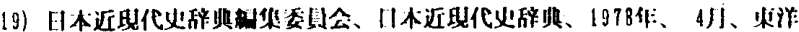

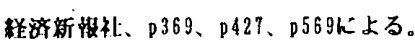

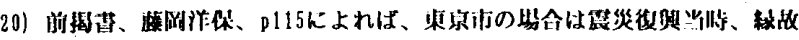
棵用が多かったと挆摘している。

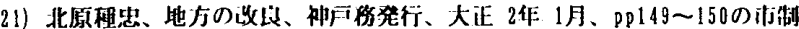

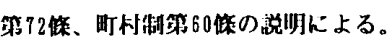

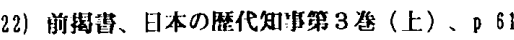

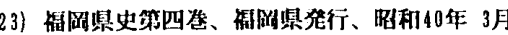

24）同赫計菖は原則的はその年の12月31日晛在の状涀を示しているが、大正

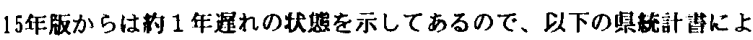
る記述ではこの点に留媓されたい。

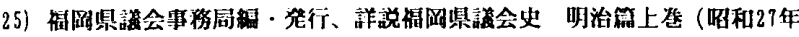
発行）、同朋治下卷（昭和28作発行）を賀科とした。

26）但し、実绦の建設は予相次淁より時間的に漣れることを你解する必要が ある。

27）土木管区の所在地は、第一が県仃内、第二が三井那北野、第三が山阴郡 楖川、第四が䩳手郡直方、第五が京都郡行橋であった。以上は祡碚貝録 明治 42 年版による。

28）本薜て使用した名酒は、明治36、39、41、43、45年斦、大正3、5、9、 11、13、15年版、昭和 4、?、9、12、13、16、18年肘である。

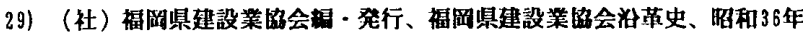

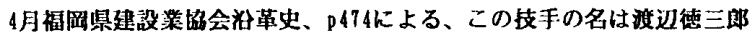

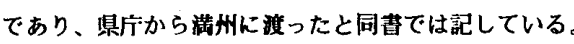

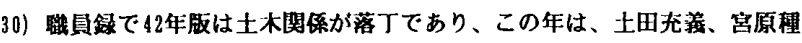

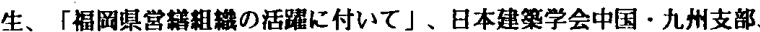

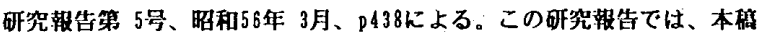
と同しょうに楅网県の営精浬と建筑課を扱っている。また三修栄三郎に

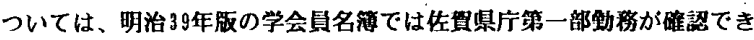
ている。

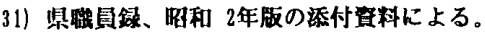

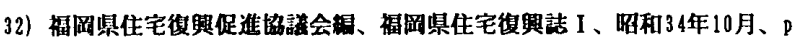
86、「1．累の機榑と如勒による。

33）前揭輩、日本の歴代知事第 3 巻（上）、D56kよる。

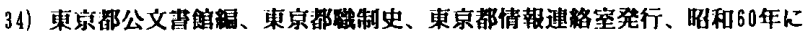
よる。但し同史では明治19年以降の記就である。また東京市については

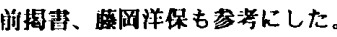

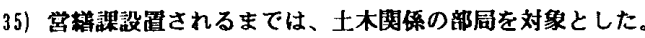

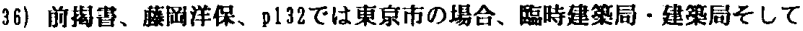

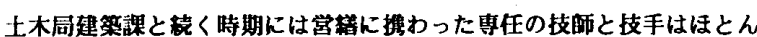
と联場を变わらなかったと指摘している。

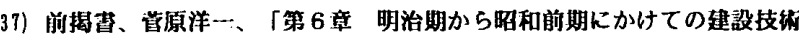

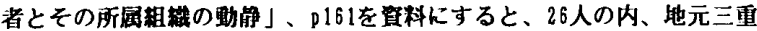

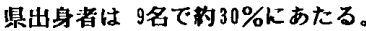

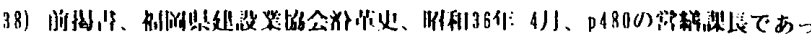

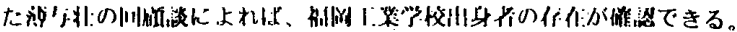

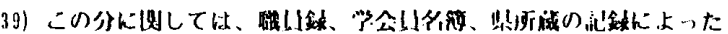

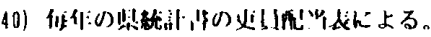

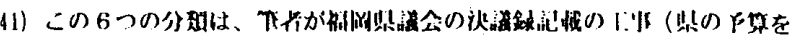

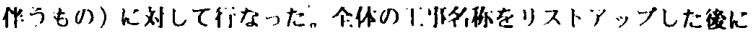

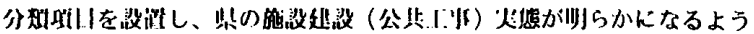

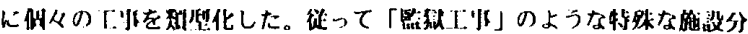

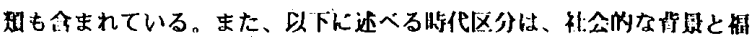

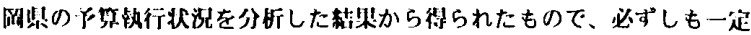

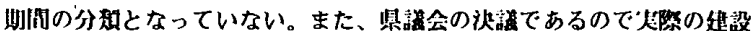
活理とは睆洞的なズレがる

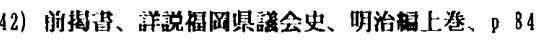

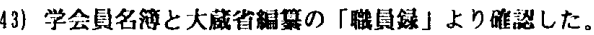

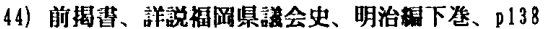

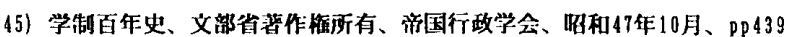
〜48kよる。

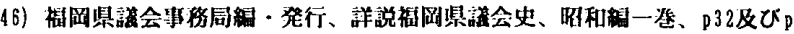

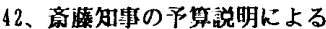

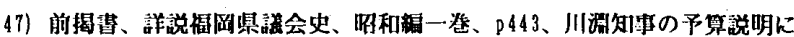
よる。

48）もっとも教有施設の中で初等教育に核当するものは、闹町村の担当のた

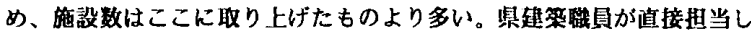
たか否かを别にすれは、、地方営楼にとって学校建筑がその多くを占めて いたことになる。

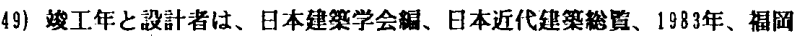
県分に゙よった。

50）前措徣、末松偖一郎、P 70kよる。

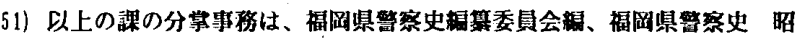

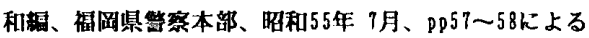

52）前揭苩、日本の歴代知事第 3 巻（上）、p56による

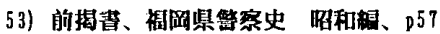

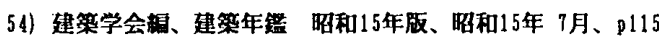

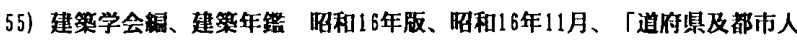

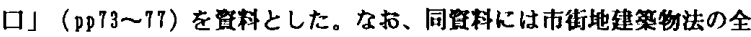
面碑用を受けた町村の人口は記されていないためこれらは除いている。

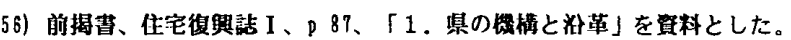
同書にはこのような指捅がある。

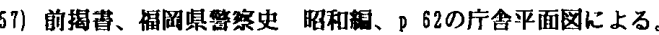

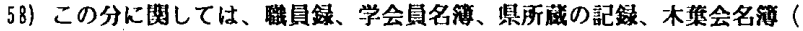
東京大学建学学科同窉会名等）によった。

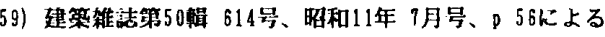

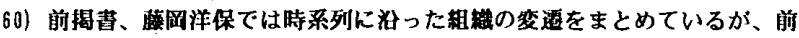

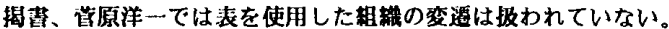

61) 炤和15年7月発行、pp 159 161

62）昭和15年股はpp84〜94、昭和16年版は11月発行でpp78〜85。正磼には昭 和10年から15年までの建設列が举げられている。

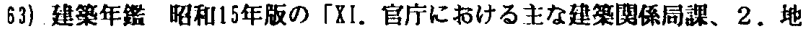
方官庁」による。 